\title{
Pollen and seed dispersal of Brazil nut trees in the southwestern Brazilian Amazon
}

\author{
Karina MARTINS ${ }^{1}$, Raifanny da Silva Oliveira dos SANTOS ${ }^{2}$, Tatiana de CAMPOS ${ }^{3}$, \\ Lúcia Helena de Oliveira WADT ${ }^{4 *}$ \\ ' Universidade Federal de São Carlos, Departamento de Biologia, Centro de Ciências Humanas e Biológicas, $18052-780$ Sorocaba, SP, Brasil \\ ${ }^{2}$ Universidade Federal do Acre, Programa de Pós-Graduação em Ecologia e Manejo de Recursos Naturais, 69920-900, Rio Branco, AC, Brasil \\ ${ }^{3}$ Empresa Brasileira de Pesquisa Agropecuária, Embrapa Acre, 69908-970, Rio Branco, AC, Brasil \\ ${ }^{4}$ Empresa Brasileira de Pesquisa Agropecuária, Embrapa Rondônia, 76815-800, Porto Velho, RO, Brasil \\ *corresponding author: lucia.wadt@embrapa.br
}

\begin{abstract}
Pollen and seed dispersal patterns greatly influence the spatial distribution of plant genetic diversity. Microsatellite-based parentage analysis provides accurate estimates of contemporary gene dispersal. Although most tropical trees have been shown to exhibit widespread pollen dispersal, few studies have estimated contemporary gene dispersal after seedling establishment. Bertholletia excelsa (Lecythidaceae) is pollinated by large-bodied bees, while previous seed-tracking experiments suggest their seeds are mainly dispersed across very short distances by scatter-hoarding rodents, who primarily act as seed predators. Here we used parentage analysis to provide contemporary estimates of pollen and seed dispersal in $B$. excelsa recruits. We examined six 25-ha plots located in two natural stands in the Acre River valley, in the southwestern Brazilian Amazon. We used 11 microsatellite markers to estimate genetic diversity and fixation index parameters in adults, seedlings and saplings. Genetic diversity was moderate and did not differ across size classes or sampling locations. We assigned pollen and seed parents for $<$ $20 \%$ of the recruits, indicating that most events of realized gene flow occurred beyond our 25-ha plots. Only 10 parentage assignments were confirmed with $80 \%$ confidence. Pollen distance ranged from 33 to $372 \mathrm{~m}$ and seed dispersal from 58 to $655 \mathrm{~m}$. Actual seed-dispersal distances were far greater than the estimates obtained in previous seed-tracking experiments. Thus, studies encompassing larger sampling areas are necessary to determine a more representative spatial scale of $B$. excelsa's pollen and seed dispersal capacity in natural stands.
\end{abstract}

KEYWORDS: Bertholletia excelsa, gene flow, genetic diversity, pollen flow, seed flow

\section{Dispersão de pólen e sementes da castanheira no sudoeste da Amazônia brasileira}

\section{RESUMO}

Os padrões de dispersão de pólen e sementes influenciam a distribuição espacial da diversidade genética. Muitas espécies arbóreas tropicais apresentam ampla dispersão de pólen, mas poucos estudos avaliaram fluxo gênico a partir de plântulas. Bertholletia excelsa (Lecythidaceae) é polinizada por abelhas e as sementes são dispersas por roedores do tipo scatter-hoarders (que estocam recursos em diferentes pontos de sua área de vida), que atuam primariamente como predadores de sementes. Experimentos de remoção de sementes tem mostrado que a dispersão de sementes por esses roedores é espacialmente limitada. Nosso objetivo foi obter estimativas de dispersão de pólen e sementes em $B$. excelsa a partir da análise de parentesco de regenerantes. Nós estudamos seis parcelas de 25 ha, em duas áreas de floresta nativa no vale do Rio Acre, no sudoeste da Amazônia brasileira. Parâmetros de diversidade genética e índice de fixaçáo foram estimados em adultos, varetas e plântulas com 11 marcadores microssatélites. A diversidade genética foi moderada e não diferiu entre classes de tamanho ou entre localidades. A paternidade foi determinada em menos de $20 \%$ dos regenerantes, indicando que a maioria dos eventos de fluxo gênico ocorreu em distâncias maiores que as encontradas nas parcelas de 25 ha. As distâncias de pólen variaram de 33 a $372 \mathrm{~m}$ e as de dispersão de sementes variaram de 58 a 655 m. As distâncias de dispersão obtidas neste estudo excedem em muito as estimativas obtidas em experimentos de remoção de sementes. Estudos envolvendo áreas maiores são necessários para que possamos aprofundar nosso conhecimento sobre capacidade de dispersão de pólen e sementes em populaçóes naturais de B. excelsa.

Palavras-CHaVe: Bertholletia excelsa, fluxo gênico, diversidade genética, fluxo de pólen, fluxo de sementes 


\section{INTRODUCTION}

In trees, patterns in pollen/seed dispersal and seedling establishment predominantly determine population genetic structure (Bacles et al. 2006). Pollen dispersal has fundamental evolutionary implications, because it significantly influences genetic processes such as gene exchange among spatially isolated populations (Wright 1946; Crawford 1984; Ennos 1994). Seed dispersal largely determines the spatial distribution of seeds and probability of seedling establishment, through the influence of density-dependent processes and other stochastic effects (Howe and Miriti 2004; Russo et al. 2006). Through its effects on recruitment patterns, seed dispersal is also shaping patters of genetic structure and diversity within and between plant populations (García and Grivet 2011). For most tree species, pollen dispersal is more important than seed-mediated gene flow in terms of contribution to total gene movement (Hamrick and Nason 2000; Petit et al. 2005). Additionally, pollen-dispersal distances and population density tend to be negatively correlated, especially in animalmediated pollination (Stacy et al. 1996; Degen et al. 2004; Dick et al. 2008).

Pollen flow patterns can be reliably characterized through paternity analysis, or progeny genotyping with microsatellites and other polymorphic molecular markers. Several paternityanalysis studies have demonstrated that most tropical trees exhibit widespread pollen dispersal (Ward et al. 2005), yet few studies have estimated contemporary gene dispersal after seedling establishment (Aldrich et al. 1998; Schnabel et al. 1998; Bacles et al. 2006; Burczyk et al. 2006; Martins et al. 2012; Baldoni et al. 2017). In fact, most estimates of seed-dispersal distances in tropical trees are based on seed- or fruit-removal experiments (Haugaasen et al. 2010; Haugaasen et al. 2012). Such studies, may underestimate actual dispersal distances, by failing to detect long-distance events (Haugaasen et al. 2012). Parentage analysis of established seedlings is a powerful strategy to provide more realistic estimates of contemporary seed dispersal (Burczyk et al. 2006; Martins et al. 2012). This technique can also estimate the relative contribution of pollen and seed movement to total gene flow.

The Brazil nut, Bertholletia excelsa Bonpl. (Lecythidaceae) is a large tree that occurs throughout terra firme forests in the Amazon basin and the Guianas (Prance 1990). Largebodied bees capable of long-distance flight (e.g. Eulaema mocsaryi and Xylocopa frontalis) are the main flower pollinators (Cavalcante et al. 2012). Bertholletia excelsa seeds are produced predominantly by cross-pollination (O'Malley et al. 1988; Wadt et al. 2015). Fruit maturation takes 14 months, resulting in a hard, large round fruit $(10-16 \mathrm{~cm}$ in diameter), containing 10-25 large seeds (Mori and Prance 1990). Fruits fall during the rainy season (November through January in the study region) (Evangelista et al. 2014), and seeds remain inside the fruit until extraction by predators capable of breaking through the hard pericarp (Haugaasen et al. 2010). These seed predators include $B$. excelsa's primary seed dispersers, the scatter-hoarding caviomorph rodents (Peres and Baider 1997; Haugaasen et al. 2010) that consume and cache seeds. Seed-tracking experiments have demonstrated that dispersal distances average $5 \mathrm{~m}$, and seeds are rarely buried beyond 20 $\mathrm{m}$ (Peres and Baider 1997). Another fruit-tracking experiment found that rodents can move fruits $15-30 \mathrm{~m}$ from their original position (Haugaasen et al. 2012). Limited seed dispersal is a major determiner of spatial genetic structure (Hardy et al. 2006), resulting in seeds germinating close to the mother trees. However, adult B. excelsa populations exhibit a very weak spatial genetic structure across the species' natural range, suggesting that effective seed-dispersal distances might be greater than existing estimates (Sujii et al. 2015).

We, thus, hypothesized that seed dispersal by scatterhoarding rodents reaches greater distances than those reported in seed- or fruit-tracking studies. Furthermore, we also hypothesized that pollen-dispersal distances are shorter in high-density stands. To test these hypotheses, we investigated two sites in the southwestern Brazilian Amazon that differ in adult density. We used 11 microsatellite loci to genotype recruits, juveniles and adults. We then performed parentage analysis to estimate pollen- and seed-dispersal distances in naturally regenerated $B$. excelsa. Finally, we compared genetic diversity and inbreeding among the recruits, juveniles and adults.

\section{MATERIAL AND METHODS}

\section{Study sites and sampling}

The two study sites were located in the Acre River valley of the Acre state (southwestern Brazilian Amazon): Seringal Filipinas (6839'50"W, 1047'06"S; within Extractive Reserve Chico Mendes) and Seringal Cachoeira (68 23'20"W, 1050'07”S; an agroextractive settlement project - PAE Chico Mendes). The sites are separated by $30 \mathrm{~km}$. Cachoeira possesses more reproductive trees per ha and fewer recruits than Filipinas, but both are considered demographically healthy (Wadt et al. 2008), despite historical B. excelsa nut harvesting.

Each site contained three permanent 9-ha $(300 \times 300 \mathrm{~m})$ plots, separated by an average of $2.2 \mathrm{~km}$ in Cachoeira and 0.8 $\mathrm{km}$ in Filipinas. Effective sampling area changed depending on tree size. Seedlings and saplings (diameter at breast height, $\mathrm{DBH}<10 \mathrm{~cm})$ were sampled in 36 subplots $(25 \times 25 \mathrm{~m}$ each) per plot. Juveniles $(10 \leq \mathrm{DBH}<30 \mathrm{~cm})$ were sampled throughout the entire 9-ha plot. To sample adults $(\mathrm{DBH} \geq$ $30 \mathrm{~cm}$ with signs of previous or current reproduction), plot borders were extended to encompass a sampling area of 25 ha $(500 \times 500 \mathrm{~m})$. All individuals were georeferenced (GPS 76CXS, Garmin). The DBH of juveniles and adults was measured. Leaves or vascular cambium were collected from all sampled individuals. Sampling was performed with permission 
from the Ministry of Environment (SISBIO licence \# 15413/1, 03/12/2008). Immediately after collection, the leaves were dried on silica gel and the vascular cambium disks were placed in microtubes containing transport buffer $(0.6$ mg of ascorbic acid, $300 \mu \mathrm{L}$ of CTAB buffer $2 \%$ (Doyle and Doyle 1987), and $700 \mu \mathrm{L}$ of absolute ethanol), on ice. Upon transport to the laboratory, the vascular cambium samples were stored at $-20^{\circ} \mathrm{C}$ and the dried leaves were stored in silica gel at room temperature $\left(23^{\circ} \mathrm{C}\right)$ until DNA extraction.

\section{Isolation and PCR of sample DNA}

A tissue disrupter (Tissue Lyser, Qiagen, Hilden, Germany) was used for DNA isolation following CTAB 2\% protocol (Doyle and Doyle 1987). Samples were quantified through visual comparison with $\lambda$ DNA standards (Invitrogen, Thermo Fisher Scientific, Vilnius, Lithuania) after 1\% agarose gel electrophoresis with $\mathrm{EtBr}$ staining. DNA samples were diluted to a final concentration of $2.5 \mathrm{ng}^{\bullet} \mu \mathrm{l}^{-1}$. We used 11 microsatellite loci: Bex 02, Bex 03, Bex 09, Bex 22, Bex 27, Bex 37 (Sujii et al. 2013); and Bes 14, Bes 13, Bes 16, Bes 18, and Bes 19 (Reis et al. 2009). The PCR reaction mixture $(13 \mu \mathrm{L})$ included 5.0 ng of genomic DNA, PCR buffer $(10 \mu \mathrm{M}$ Tris- $\mathrm{HCl}, 50 \mu \mathrm{M} \mathrm{KCl})$, BSA $(0.25$ $\left.\mathrm{mg} \bullet \mathrm{mL}^{-1}\right)$, dNTPs $(0.25 \mathrm{mM})$, forward/reverse primers $(0.27 \mu \mathrm{M}), 1 \mathrm{U}$ Taq DNA polymerase (Invitrogen, Thermo Fisher Scientific), and ultrapure water. Amplification was performed in a MJ 96+ thermocycler (Biocycler, Hangzhou, China) following published procedures Don et al. (1991). Amplified fragments were separated through $5 \%$ polyacrylamide gel and visualized with silver nitrate staining, in accordance with previously described protocol Creste et al. (2001). A10-bp ladder (Invitrogen, Thermo Fisher Scientific) was used as the size standard.

\section{Statistical analysis}

Individuals were grouped in three size classes based on DBH: recruits (seedlings and saplings), juveniles and adults. For each class, the following parameters of genetic diversity and inbreeding were estimated in FSTAT (Goudet 1995): average number of alleles per locus $(A)$, allelic richness $\left(R_{\mathrm{S}}\right)$ according to El Mousadik and Petit (1996), expected heterozygosity $\left(H_{\mathrm{E}}\right)$, and inbreeding coefficient $\left(F_{\mathrm{IS}}\right)$. Between-class variation in genetic diversity were analyzed with the Kruskal-Wallis $\mathrm{H}$ test in R ( $\mathrm{R}$ Core Team 2015). Between-class divergence $\left(\theta_{\mathrm{p}}\right)$ per site was also estimated. The $99 \%$ confidence intervals for both and were obtained through bootstrapping over loci.

Contemporary gene flow through pollen and seed dispersal was estimated with parentage analyses and maximum likelihood in CERVUS v. 3.0.7 (Kalinowski et al. 2007). Possible pollen donors and seed trees of all recruits (DBH $\leq 10 \mathrm{~cm}$ ) per site were determined by genotyping with at least eight microsatellites. Because all experimental plots are situated within a continuous forest containing potential parents outside plot borders and between plots, parentage was analyzed per plot. All sampled trees with $\mathrm{DBH} \geq 50 \mathrm{~cm}$ in extended plots were considered candidate parents of same-plot recruits. Despite being reproductive and classified as adults, trees with DBH between 30 to $50 \mathrm{~cm}$ were excluded to yield more conservative parentage assignments.

Parentage confidence was obtained via simulation, specifically by calculating critical delta statistics with a confidence threshold of $80 \%$. In our simulations, $90 \%$ of candidate parents and microsatellites were correctly assigned and genotyped while $1 \%$ of loci were mistyped. A given parentage assignment was confirmed via a comparison of actual delta statistics with the simulated critical delta. In Cachoeira, combined exclusionary power for parent pairs was $8 \times 10^{-5}$. The parentage analysis included only samples genotyped with eight or more loci, resulting in 95 candidate parents and 26 recruits. In Filipinas, combined exclusionary power was $3.5 \times 10^{-4} ; 47$ candidate parents and 64 recruits were tested.

Under the assumption of limited seed-dispersal distance, the nearest adult candidate matching a recruit was classified as the seed parent. This conservative approach has been successfully used for monoecious and hermaphroditic species with known short-distance seed dispersal (Bacles et al. 2006; OddouMuratorio and Klein 2008; Nakanishi et al. 2009; Sebbenn et al. 2011; Martins et al. 2012). Pollen dispersal was calculated as distance between parents of a given recruit, while seed dispersal was the distance between recruits and their seed trees.

\section{RESULTS}

Adult density was almost threefold greater in Cachoeira (1.7 adults.ha $\left.{ }^{-1}\right)$ than in Filipinas $\left(0.62\right.$ adults $\left.\cdot \mathrm{ha}^{-1}\right)$, but the latter contained twice as many recruits as the former. Despite samplesize differences, allelic diversity $(A)$ was similar across size classes and sites (Kruskal-Wallis test, $>0.05$ in all comparisons) (Table 1 ). Overall $R_{\mathrm{S}}$ and $H_{\mathrm{E}}$ did not vary significantly between sites (Kruskal-Wallis test, $p>0.05$ ). Additionally, we found no evidence of inbreeding (Table 1). Size classes were more similar at Cachoeira $\left(\theta_{\mathrm{p}}=0.023 ; \mathrm{CI}_{99 \%}=-0.003,0.081\right)$ than at Filipinas, where significant between-class differentiation was observed $\left(\theta_{\mathrm{p}}\right.$ $\left.=0.049 ; \mathrm{CI}_{99 \%}=0.008,0.131\right)$.

Each site contained five parentage lines (both parents successfully assigned), representing $7.8 \%$ and $19.2 \%$ of the recruits in Filipinas and Cachoeira, respectively (Table 2). Parentage assignments involved a minimum of 10 loci, except one assignment in Cachoeira with eight. Assignment confidence was $95 \%$ in only one test (Table 3). Few parents were present inside the 25-ha plots, indicating most actual gene flow occurred at > $500 \mathrm{~m}$. Estimates of pollen- and seed-dispersal distances were very similar between the two sites (Table 3; pollen: $H=0.27$, $d f=1, p=0.601$; seed: $H=2.45, d f=1, p=0.117$ ). Mean pollendispersal distance was $198.7 \pm 110.0 \mathrm{~m}$ and mean seed-dispersal distance was $263 \pm 188.2 \mathrm{~m}$. 
Table 1. Estimates of genetic diversity and inbreeding in three Bertholletia excelsa DBH classes in two study sites in Acre (southwestern Brazilian Amazon), obtained with 11 SSR loci. $N=$ sample size, $k=$ total number of alleles, $A=$ average number of alleles per locus, $R_{\mathrm{s}}=$ allele richness based on a minimum sample size of $6, H_{\mathrm{E}}=$ expected heterozygosity, $F_{15}=$ inbreeding coefficient, $\mathrm{SE}=$ standard error, $\mathrm{Cl}_{99 \%}=99 \%$ confidence interval of $F_{15}$ obtained by bootstraps over loci.

\begin{tabular}{|c|c|c|c|c|c|c|}
\hline & \multicolumn{3}{|c|}{ Filipinas } & \multicolumn{3}{|c|}{ Cachoeira } \\
\hline & recruits & juveniles & adults & recruits & juveniles & adults \\
\hline N & 64 & 11 & 47 & 26 & 21 & 105 \\
\hline k & 46 & 33 & 54 & 45 & 50 & 56 \\
\hline$A(\mathrm{SE})$ & $4.18(0.63)$ & $3.00(0.27)$ & $4.91(0.78)$ & $4.09(0.56)$ & $4.55(0.58)$ & $5.09(0.71)$ \\
\hline$R_{5}(\mathrm{SE})$ & $2.95(0.36)$ & $2.88(0.26)$ & $3.43(0.40)$ & $3.36(0.39)$ & $3.62(0.36)$ & $3.50(0.34)$ \\
\hline$H_{E}(S E)$ & $0.490(0.076)$ & $0.541(0.054)$ & $0.571(0.065)$ & $0.563(0.062)$ & $0.618(0.045)$ & $0.581(0.058) \mathrm{H}$ \\
\hline$F_{15}$ & -0.049 & -0.093 & -0.043 & 0.071 & 0.059 & -0.053 \\
\hline $\mathrm{Cl}_{99 \%}$ & $-0.020-0.069$ & $-0.270-0.070$ & $-0.197-0.112$ & $-0.006-0.142$ & $-0.072-0.198$ & $-0.117-0.010$ \\
\hline
\end{tabular}

Table 2. Sample size, and number and proportion of confirmed parentages of Bertholletia excelsa in the Filipinas and Cachoeira study sites in Acre (southwestern Brazilian Amazon). $\mathrm{N}=$ number of individuals; candidates = trees genotyped with at least 6 loci.

\begin{tabular}{|c|c|c|c|c|c|c|c|}
\hline \multicolumn{4}{|c|}{ Filipinas } & \multicolumn{4}{|c|}{ Cachoeira } \\
\hline Plot & $\begin{array}{l}\mathrm{N} \text { adults/N } \\
\text { candidates }\end{array}$ & $\mathrm{N}$ recruits & $\begin{array}{l}\mathrm{N} \text { confirmed parentages } \\
(\%)\end{array}$ & Plot & $\begin{array}{l}\mathrm{N} \text { adults/ } \mathrm{N} \\
\text { candidates }\end{array}$ & $\mathrm{N}$ recruits & $\begin{array}{c}\text { N confirmed parentages } \\
(\%)\end{array}$ \\
\hline 1 & $15 / 11$ & 16 & $2(12.5)$ & 5 & $45 / 42$ & 16 & $3(18.8)$ \\
\hline 3 & $10 / 8$ & 35 & $1(0.03)$ & 6 & $40 / 40$ & 10 & $2(20.0)$ \\
\hline 4 & $22 / 17$ & 13 & $2(15.5)$ & $7^{*}$ & - & - & - \\
\hline Total & - & 64 & $5(7.8)$ & Total & - & 26 & $5(19.2)$ \\
\hline
\end{tabular}

* all saplings were genotyped with less than 6 loci in plot 7

Table 3. Pollen and seed dispersal distances estimated for Bertholletia excelsa recruits (seedlings and saplings) in the Filipinas and Cachoeira study sites in Acre (southwestern Brazilian Amazon)

\begin{tabular}{|c|c|c|c|c|c|c|c|}
\hline locality & plot & recruit ID & seed tree ID & pollen tree ID & confidence & seed distance $(m)$ & pollen distance $(\mathrm{m})$ \\
\hline Filipinas & 1 & 1P07/08 & 95 & 83 & $80 \%$ & 271 & 245 \\
\hline Filipinas & 1 & $1-2008-6$ & 95 & 93 & $80 \%$ & 439 & 82 \\
\hline Filipinas & 3 & 3P19 & 447 & 534 & $80 \%$ & 167 & 158 \\
\hline Filipinas & 4 & 4-2010-4 & 393 & 391 & $80 \%$ & 178 & 310 \\
\hline Filipinas & 4 & $4 \times 3-$ & 356 & 372 & $80 \%$ & 437 & 101 \\
\hline Mean (SD) & & & & & & $298(133.5)$ & $179(97.0)$ \\
\hline Median & & & & & & 271 & 158 \\
\hline Range & & & & & & $167-439$ & $82-310$ \\
\hline Cachoeira & 5 & 5LV003 & D13 & 244 & $95 \%$ & 58 & 372 \\
\hline Cachoeira & 5 & 5-2010-1 & D9 & D36 & $80 \%$ & 145 & 261 \\
\hline Cachoeira & 5 & 5-2010-2 & D9 & D5 & $80 \%$ & 655 & 33 \\
\hline Cachoeira & 6 & $6 \mathrm{P3}$ & N48 & 184 & $80 \%$ & 115 & 275 \\
\hline Cachoeira & 6 & $6-2008-5 a$ & $\mathrm{~N} 20$ & N19 & $80 \%$ & 165 & 150 \\
\hline Mean (SD) & & & & & & $228(242)$ & $218(130)$ \\
\hline Median & & & & & & 145 & 261 \\
\hline Range & & & & & & $58-655$ & $33-372$ \\
\hline
\end{tabular}




\section{DISCUSSION}

Our study revealed that B. excelsa seeds were dispersed beyond $500 \mathrm{~m}$, a distance far greater than those estimated by previous estimates based on seed- and fruit-tracking experiments (Peres and Baider 1997; Haugaasen et al. 2012). This outcome supports our hypothesis that seed dispersal agents (e.g., scatter-hoarders such as agoutis) are carrying seeds farther away than previously supposed. Similarly, parentage-based seed-dispersal distances (Martins et al. 2012) were far greater than estimates from seed-tracking experiments (Silva 2009) in Carapa guianensis (another large-seeded tree dependent on scatter-hoarder dispersers), even when the two experiments were conducted at the same site. Thus, at least for these two species, scatter-hoarder rodents are more effective at longdistance seed dispersal than previously thought.

We note that because the sampling area for candidate parents was $25 \mathrm{ha}$, and $>80 \%$ of recruits were not in the same plot as their parents, the estimate of pollen- and seeddispersal distances was extremely conservative. In addition, plot size limited the maximum observable dispersal distance in this study, as did the small number of recruits, especially in Cachoeira. Given that sampling design and number of parentage assignments are highly influential in propaguledispersal estimates, we recommend increasing sampling areas in future studies to better access the upper limit of $B$. excelsa's seed-dispersal capacity in natural stands.

As Cachoeira contained three times more adults than Filipinas, we expected to assign more parents and observe smaller pollen-dispersal distances. Indeed, several studies have verified a negative correlation between mean distance among flowering trees and average pollen dispersal distance (Stacy et al. 1996; Degen et al. 2004; Carneiro et al. 2007; Lacerda et al. 2008). A recent parentage analysis in B. excelsa found that most pollination events occurr between nearest neighbors (Baldoni et al. 2017), a pattern that reflects the expected foraging behavior of pollinators. In our populations, the mean distances between reproductive trees $(-200 \mathrm{~m}$ in Filipinas and $-248 \mathrm{~m}$ in Cachoeira) matched average pollen-dispersal distance, but the low number of parentage assignments precluded statistical analysis. Given the lack of parentage for most recruits in our study, we believe pollinators are bypassing the nearest-neighbor trees and dispersing pollen at distances $>500 \mathrm{~m}$ (maximum pairwise distance between adults in our plots). This phenomenon may occur owing to pollen carryover or asynchronous flowering (Dick et al. 2008) and has been observed in other low-density tree populations (Stacy et al. 1996; Martins et al. 2012).

Effective gene flow is crucial to maintaining genetic diversity in natural populations. Adults and recruits in our study had similar genetic diversity to what was observed in other B. excelsa populations studied in Acre (Santos et al. 2017) and across the Brazilian Amazon (Sujii et al. 2015).
Specifically, B. excelsa populations are less genetically diverse than other tropical trees (Azevedo et al. 2007; Cloutier et al. 2007; Raposo et al. 2007; André et al. 2008; Martins et al. 2012). This low genetic diversity has been confirmed in studies relying on other types of molecular markers (O'Malley et al. 1988; Kanashiro et al. 1997), suggesting that it is characteristic of this species. Moreover, the absence of inbreeding in our populations, along with the relative lack of fine-scale spatial genetic structure in natural stands (Sujii et al. 2015; Baldoni et al. 2017) are congruent with the high pollen and seed dispersal in B. excelsa.

\section{CONCLUSIONS}

In this study, we used parentage analysis to provide accurate estimates of contemporary pollen- and seed-dispersal distances in natural Bertholletia excelsa populations. We demonstrated a high capacity of gene flow through both pollen and seed movement. Parentage analyses estimated longer seed-dispersal distances than did previous seed-tracking experiments. Indeed, most sampled recruits were not in the same plot as their parents. Based on these data, we recommend that future studies addressing contemporary gene dispersal in B. excelsa consider a larger sampling area.

\section{ACKNOWLEDGMENTS}

This project was funded by Conselho Nacional de Desenvolvimento Científico e Tecnológico - CNPq (grant \# 480016/2008-9) and Fundo de Desenvolvimento Científico e Tecnológico do Estado do Acre (FDCT/FUNTAC - grant \# 020/2009). RSOS received a scholarship from Coordenação de Aperfeiçoamento de Pessoal de Nível Superior - CAPES. We thank the Empresa Brasileira de Pesquisa Agropecuária EMBRAPA staff for field and laboratory support. We are most grateful to the extractivist families who shared their forest home. A professional from editage.com.br revised the language.

\section{REFERENCES}

Aldrich, P.R.; Hamrick, J.H.; Chavarriaga, P.; Kochert, G. 1998. Microsatellite analysis of demographic genetic structure in fragmented populations of the tropical tree Symphonia globulifera. Molecular Ecology, 7: 933-944.

André, T.; Lemes, M.R.; Grogan, J.; Gribel, R. 2008. Post-logging loss of genetic diversity in a mahogany (Swietenia macrophylla King, Meliaceae) population in Brazilian Amazonia. Forest Ecology and Management, 255: 340-345.

Azevedo, V.C.; Kanashiro, M.; Ciampi, A.Y.; Grattapaglia, D. 2007. Genetic structure and mating system of Manilkara huberi (Ducke) A. Chev., a heavily logged Amazonian timber species. Journal of Heredity, 98: 646-54.

Bacles, C.F.E.; Lowe, A.J.; Ennos, R.A. 2006. Effective seed dispersal across a fragmented landscape. Science, 311: 628. 
Baldoni, A.B.; Wadt, L.H.O.; Campos, T.; Silva, V.S.; Azevedo, V.C.R.; Mata, L.R.; et al. 2017. Contemporary pollen and seed dispersal in natural populations of Bertholletia excelsa (Bonpl.). Genetics and Molecular Research, 16: gmr16039756.

Burczyk, J.; Adams, W.T.; Birkes, D.S.; Chybicki, I.J. 2006. Using genetic markers to directly estimate gene flow and reproductive success parameters in plants on the basis of naturally regenerated seedlings. Genetics, 173: 363-72.

Carneiro, F.S.; Sebbenn, A.M.; Kanashiro, M.; Degen, B. 2007. Low interannual variation in mating system and gene flow of Symphonia globulifera in the Brazilian Amazon. Biotropica, 39: 628-636.

Cavalcante, M.C.; Oliveira, F.F.; Maués, M.M.; Freitas, B.M. 2012. Pollination requirements and the foraging behavior of potential pollinators of cultivated Brazil Nut (Bertholletia excelsa Bonpl.) trees in central Amazon rainforest. Psyche: A Journal of Entomology, 2012: 978019.

Cloutier, D.; Kanashiro, M.; Ciampi, A.Y.; Schoen, D.J. 2007. Impact of selective logging on inbreeding and gene dispersal in an Amazonian tree population of Carapa guianensis Aubl. Molecular Ecology, 16: 797-809.

Crawford, T.J. 1984. The estimation of neighbour parameters for plant populations. Heredity, 52: 273-283.

Creste, S.; Tulmann-Neto, A.; Figueira, A. 2001. Detection of single sequence repeat polymorphisms in denaturing polyacrylamide sequencing gels by silver staining. Plant Molecular Biology Reporter, 19: 299-306.

Degen, B.; Bandou, E.; Caron, H. 2004. Limited pollen dispersal and biparental inbreeding in Symphonia globulifera in French Guiana. Heredity, 93: 585-91.

Dick, C.W.; Hardy, O.J.; Jones, F.A.; Petit, R.J. 2008. Spatial scales of pollen and seed-mediated gene flow in tropical rain forest trees. Tropical Plant Biology, 1: 20-33.

Don, R.H.; Cox, P.T.; Wainwright, B.J.; Baker, K.; Mattick, J.S. 1991. 'Touchdown' PCR to circumvent spurious priming during gene amplification. Nucleic Acid Research, 19: 4008.

Doyle, J.J.; Doyle, J.L. 1987. A rapid DNA isolation procedure for small quantities of fresh leaf tissue. Phytochemical Bulletin, 19: 11-15.

El Mousadik, A.; Petit, R.J. 1996. High level of genetic differentiation for allelic richness among populations of the argan tree [Argania spinosa (L.) Skeels] endemic to Morocco. Theoretical and Applied Genetics, 92: 832-839.

Ennos, R.A. 1994. Estimating the relative rates of pollen and seed migration among populations. Heredity, 72: 250-259.

Evangelista, J.S.; Correa, M.F.; Reis, S.F.; Fonseca, F.L.; Wadt, L.H.O. 2014. Comportamento fenológico de Bertholletia excelsa Bonpl. e Carapa guianensis Aubl. durante oito anos, na Amazônia Sul-Ocidental. Anais/Resumos 66a Reunião Anual da SBPC. Sociedade Brasileira para o Progresso da Ciência, Rio Branco, AC.

García, C.; Grivet, D. 2011. Molecular insights into seed dispersal mutualisms driving plant population recruitment. Acta Oecologica, 37: 632-640.
Goudet, J. 1995. FSTAT (version 1.2): a computer program to calculate F-statistics. Journal of Heredity, 86: 485-486.

Hamrick, J.L.; Nason, J.D. 2000. Gene flow in forest trees. In: Hamrick, J.L.; Nason, J.D. (Ed.). Forest Conservation Genetics: Principles and Practice. CSIRO Publishing, Collingwood, Australia, p.81-90.

Hardy, O.J.; Maggia, L.; Bandou, E.; Breyne, P.; Caron, H.; Chevallier, M.H.; et al. 2006. Fine-scale genetic structure and gene dispersal inferences in 10 neotropical tree species. Molecular Ecology, 15: 559-571.

Haugaasen, J.M.T.; Haugaasen, T.; Peres, C.A.; Gribel, R.; Wegge, P. 2010. Seed dispersal of the Brazil nut tree (Bertholletia excelsa) by scatter-hoarding rodents in a central Amazonian forest. Journal of Tropical Ecology, 26: 251-262.

Haugaasen, J.M.T.; Haugaasen, T.; Peres, C.A.; Gribel, R.; Wegge, P. 2012. Fruit removal and natural seed dispersal of the Brazil nut tree (Bertholletia excelsa) in Central Amazonia, Brazil. Biotropica, 44: 205-210.

Howe, R.F.; Miriti, M.N. 2004. When seed dispersal matters. BioScience, 54: 651-660.

Kalinowski, S.T.; Taper, M.L.; Marshall, T.C. 2007. Revising how the computer program CERVUS accommodates genotyping error increases success in paternity assignment. Molecular Ecology, 16: 1099-1106.

Kanashiro, M.; Harris, S.A.; Simons, A. 1997. RAPD Diversity in Brazil nut (Bertholletia excelsa Humb. and Bonpl., Lecythidaceae). Silvae Genetica, 46: 219-223.

Lacerda, A.E.B.; Kanashiro, M.; Sebbenn, A.M. 2008. Long-pollen movement and deviation of random mating in a low density continuous population of Hymenaea courbaril in the Brazilian Amazon. Biotropica, 40: 462-470.

Martins, K.; Raposo, A.; Klimas, C.A.; Veasey, E.A.; Kainer, K.; Wadt, L.H.O. 2012. Pollen and seed flow patterns of Carapa guianensis Aublet. (Meliaceae) in two types of Amazonian forest. Genetics and Molecular Biology, 35: 818-826.

Mori, S.A.; Prance, G.T. 1990. Taxonomy, ecology and economic botany of the Brazil nut (Bertholletia excelsa Humb. \& Bonpl.: Lecythidaceae). Advances in Economic Botany, 8: 130-150.

Nakanishi, A.; Tomaru, N.; Yoshimaru, H.; Manabe, T.; Yamamoto, S. 2009. Effects of seed- and pollen-mediated gene dispersal on genetic structure among Quercus salicina saplings. Heredity, 102: 182-189.

O'Malley, R.C.; Buckley, D.P.; Prance, G.T.; Bawa, K.S. 1988. Genetics of Brazil nut (Bertholletia excelsa Humb. \& Bonpl.:Lecythidaceae) 2. Mating system. Theoretical and Applied Genetics, 76: 929-932.

Oddou-Muratorio, S.; Klein, E.K. 2008. Comparing direct vs. indirect estimates of gene flow within a population of a scattered tree species. Molecular Ecology, 17: 2743-54.

Peres, C.A.; Baider, C. 1997. Seed dispersal, spatial distribution and population structure of Brazil nut trees (Berthollethia excelsa) in southeastern Amazonia. Journal of Tropical Ecology, 13: 595-616.

Petit, R.J.; Duminil, J.; Fineschi, S.; Hampe, A.; Salvini, D.; Vendramin, G.G. 2005. Comparative organization of 
chloroplast, mitochondrial and nuclear diversity in plant populations. Molecular Ecology, 14: 689-701.

Prance, G.T. 1990. Bertholletia. In: Prance, G.T. (Ed.). Lecythidaceae. Part II. The Zygomorphic-Flowered New World Genera. New York Botanical Garden, Bronx, NY, p. 114-118.

R Core Team. 2015. R: A language and environment for statistical computing. R Foundation for Statistical Computing, Vienna, Austria

Raposo, A.; Martins, K.; Ciampi, A.Y.; Wadt, L.H.d.O.; Veasey, E.A. 2007. Diversidade genética de populaçôes de andiroba no Baixo Acre. Pesquisa Agropecuária Brasileira, 42: 1291-1298.

Reis, A.M.M.; Braga, A.C.; Lemes, M.R.; Gribel, R.; Collevatti, R.G. 2009. Development and characterization of microsatellite markers for the Brazil nut tree Bertholletia excelsa Humb. \& Bonpl. (Lecythidaceae). Molecular Ecology Resources, 9: 920-923.

Russo, S.E.; Portnoy, S.; Augspurger, C.K. 2006. Incorporating animal behavior into seed dispersal models: implications for seed shadows. Ecology, 87: 3160-3174.

Santos, R.S.O.d.; Campos, T.; Martins, K.; Wadt, L.H.O. 2017. Estrutura genética de duas populações naturais de Bertholletia excelsa Bonpl. sob exploração no Vale do Rio Acre. Biota Amazônia, 37: 37-40.

Schnabel, A.; Nason, J.D.; Hamrick, J.L. 1998. Understanding the population genetic structure of Gleditsia triacanthos L.: seed dispersal and variation in female reproductive success. Molecular Ecology, 7: 819-832.

Sebbenn, A.M.; Carvalho, A.C.; Freitas, M.L.; Moraes, S.M.; Gaino, A.P.; da Silva, J.M.; Jolivet, C.; Moraes, M.L. 2011. Low levels of realized seed and pollen gene flow and strong spatial genetic structure in a small, isolated and fragmented population of the tropical tree Copaifera langsdorffii Desf. Heredity, 106: 134-145.
Silva, A.C.C. 2009. Remoção e destino de sementes de Carapa guianensis Aubl. (Meliaceae) e Bertholletia excelsa Bonpl. (Lecythidaceae) no sudoeste do estado do Acre, Brasil. Master's thesis, Universidade Federal do Acre, Rio Branco, Acre. 153p.

Stacy, E.A.; Hamrick, J.L.; Nason, J.D.; Hubbell, S.P.; Foster, R.B.; Condit, R. 1996. Pollen dispersal in low-density populations of three neotropical tree species. The American Naturalist, 148: 276-298.

Sujii, P.S.; Inglis, P.W.; Ciampi, A.Y.; Solferini, V.N.; Azevedo, V.C.R. 2013. Isolation and characterization of microsatellite markers for Bertholletia excelsa (Lecythidaceae) population genetic analysis. Genetics and Molecular Research, 12: 5278-5282.

Sujii, P.S.; Martins, K.; Wadt, L.H.O.; Azevedo, V.C.R.; Solferini, V.N. 2015. Genetic structure of Bertholletia excelsa populations from the Amazon at different spatial scales. Conservation Genetics, 16: 955-964.

Wadt, L.H.O.; Kainer, K.A.; Staudhammer, C.L.; Serrano, R.O.P. 2008. Sustainable forest use in Brazilian extractive reserves: Natural regeneration of Brazil nut in exploited populations. Biological Conservation, 141: 332-346.

Wadt, L.H.O.; Baldoni, A.B.; Silva, V.S.; Campos, T.; Martins, K.; Azevedo, V.C.R.; et al. 2015. Mating system variation among populations, individuals and within and among fruits in Bertholletia excelsa. Silvae Genetica, 64: 248-259.

Ward, M.; Dick, C.W.; Gribel, R.; Lowe, A.J. 2005. To self, or not to self... a review of outcrossing and pollen-mediated gene flow in neotropical trees. Heredity, 95: 246-254.

Wright, S. 1946. Isolation by distance under diverse systems of mating. Genetics, 31: 39-59.

RECEIVED: 02/01/2018

ACCEPTED: 06/05/2018

ASSOCIATE EDITOR: Alexandre Pio Viana 